\title{
Gujarat Charanka Solar Park
}

\section{Prasanth Elavarthi}

Gujarat Solar Park is the world's first multi developer, multi facility, multi technology and multi beneficiary solar park located in 2,000-hectare (4,900-acre) plot of land near Charanka village in Patan district, northern Gujarat. This is the Asia's largest solar park hub. This project is Honorable Prime Minister Mr. NarendraModi pet project and because of his initiative in Gujarat the Solar has taken birth in India. The Gujarat Solar Park hosts about 17 different projects by different developers. As on April 2014, a total of 221 megawatts had been commissioned. It also became the world's second largest photovoltaic power station. When fully built out, the Charanka Solar Park will host $500 \mathrm{MW}$ of solar power systems using state-of-the-art thin film and crystalline technology. The investment cost for the Charanka solar park amounts to US\$280 million, the construction began on December 3, 2010. The solar park is expected to save around 8 million tonnes of carbon dioxide from being released into the atmosphere and save around 900,000 tonnes of natural gas per year.The Gujarat government has signed Power purchase agreement (PPA) with developers for Rs15 (about USD 0.29) per kWh for the first 12 years and Rs 5 (about USD 0.10) per kWh from the 13th to 25 th year. The national solar policy has fixed tariffs of Rs17 for photovoltaic and Rs15 for solar thermal for 25 years.

\section{Key Features of the solar park:}

$>$ Firstof its kind inthe world

$>$ FastestImplementation

$>$ MultiDeveloper,Multi FacilityMultiTechnologyandMulti BeneficiarySolarPark

$>$ IntegratedhubofSolarpowergeneration

$>$ UniqueIntegrationofEnvironmentbenefit,Infrastructure developmentandSocial up gradation

$>$ Benchmarkprojectfor other states.

$>$ HybridizationofWind and Solar

$>$ Upgradationin the standard ofliving in the rural area

$>$ Utilization of waste lands

$>$ Local employment

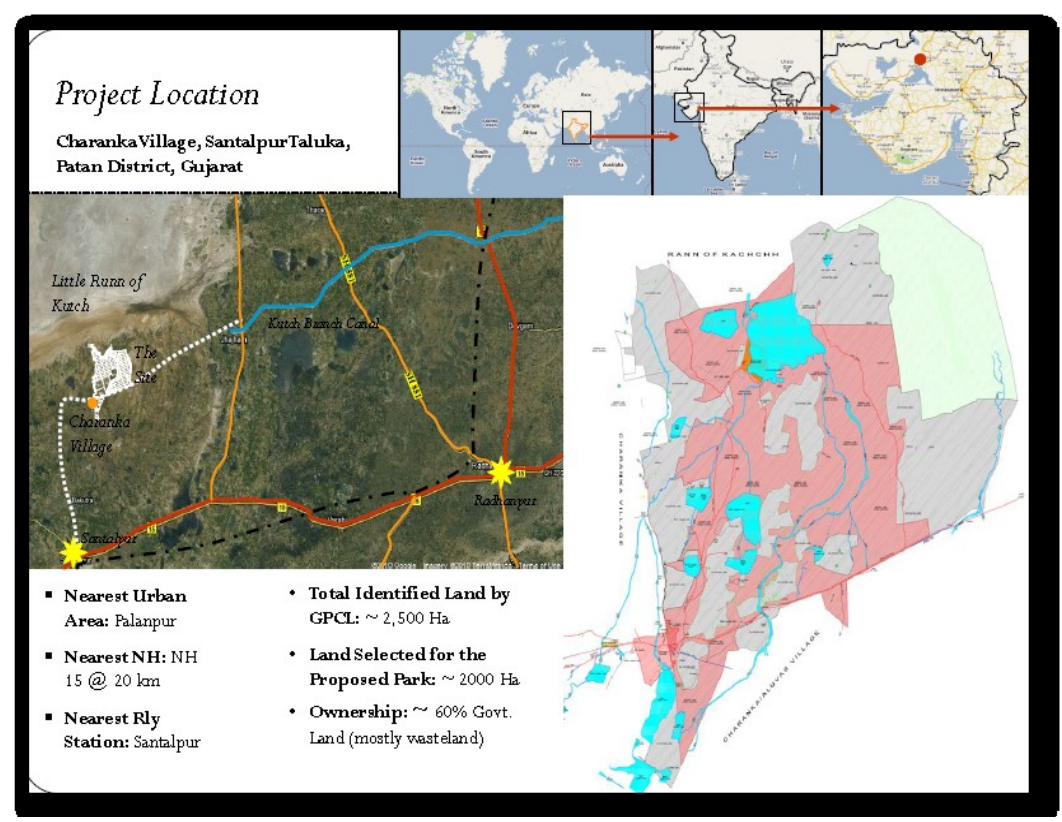




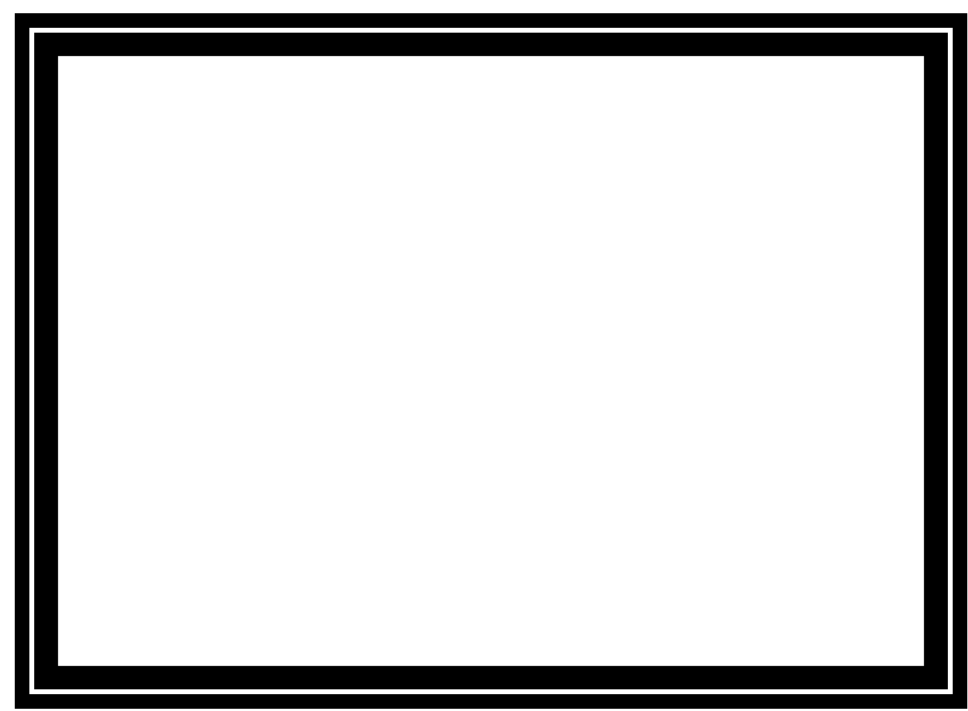

\section{Infrastructure provided in the solar park:}

$>$ Roads

$>$ RawWaterPipeline

$>$ Rehabilitationof existingreser voir

$>$ WaterTreatmentPlant

$>$ WaterDistributionNetwork

$>$ WaterTank(GLSR/OHT)

$>$ SewageTreatmentPlant

$>$ 400/220/66KV\&66KVAuxiliarySS

$>$ AuxiliaryPowerDistributionNetwork

$>$ TelecomNetwork

$>$ Fencing(Boundary)

$>$ Compoundwall

$>$ Entrance

$>$ SecurityTowers

$>$ TrainingInstitute

$>$ Commonfacilities

$>$ Helipad

$>$ Greenbelt / buffer

$>$ Watertomeet the irrigationdemand

$>$ Landscaping

$>$ Internal(plot) fencing

$>$ Landlevelling/Grading

$>$ Fire Station

\subsection{TangibleBenefits:}

\section{Benefits of Charanka Solar Park:}

$>$ Basicinfrastructuredevelopmentbenefits sharedwithlocal villages

$>$ Communicationnetwork

$>$ Provisionoflrrigationwater

$>$ Developerinvestmentof Rs. $3600 \mathrm{Cr}$

$>$ Employmentgenerationofabout1500 labours

$>$ Economicupliftmentofruralarea

12 IntangibleBenefits

$>$ IncreaseinWaterconservation

$>$ IncreaseinVegetationcover

$>$ Reductionindesertificationprocess

$>$ CarbonEmission reduction

$>$ Increaseinaesthetic valueofarea

$>$ Socialupliftment 
IV. List of Project developers in Charanka Solar Park:

\begin{tabular}{|c|c|c|c|c|c|c|c|}
\hline S.No & Name of the Party & $\begin{array}{c}\text { Capacity } \\
(\mathrm{MW})\end{array}$ & $\begin{array}{c}\text { Module } \\
\text { Type }\end{array}$ & $\begin{array}{l}\text { Module } \\
\text { Make }\end{array}$ & Inverter Type & $\begin{array}{c}\text { Inverter } \\
\text { Make }\end{array}$ & Tilt \\
\hline 1 & GMR Guja rat solar power pvt.Itd & 25 & Crystalline Si & Canadian Solar & Central Inverter & SMA & Fixed Tilt \\
\hline 2 & Sun Clean Renewable pvt.Itd & 6 & Thin Film & Sharp & Central Inverter & Power-One & Fixed Tilt \\
\hline 3 & Emami Cement Itd & 10 & Crystalline Si & TATA BP & Central Inverter & $A B B$ & Seasonal Tilt \\
\hline 4 & Solarfield Energy Pvt. Ltd. & 20 & Thin Film & Sharp & Central Inverter & Sharp & Fixed Tilt \\
\hline 5 & SEl Solar Power Guja rat pvt.Itd & 25 & Crystalline Si & Chint/Trina & Central Inverter & Power One & Fixed Tilt \\
\hline 6 & GSPC Pipavav Power Company Itd. & 5 & Crystalline Si & Suntech & Central Inverter & Bonfiglioli & Fixed Tilt \\
\hline 7 & AES Solar Energy Guja rat pvt. Ltd & 15 & Thin Film & First Solar & Central Inverter & Power One & Fixed Tilt \\
\hline 8 & Alex Astral Power pvt.Itd & 25 & Thin Film & First Solar & Central Inverter & SMA & Fixed Tilt \\
\hline 9 & NKG Infrastructure Itd & 10 & Crystalline Si & Solarworld & String Inverter & Delta (String) & Fixed Tilt \\
\hline 10 & Palace Solar Energy pvt.Itd & 15 & Crystalline $\mathrm{Si}$ & Candian Solar & Central Inverter & Power One & Seasonal Tilt \\
\hline 11 & Roha Dyechem pvt.Itd & 25 & Thin Film & Nexpower & Central Inverter & Satcon & Seasonal Tilt \\
\hline 12 & Lanco Infratech Itd. & 15 & Crystalline Si & C-Sun & Central Inverter & Bonfiglioli & Fixed Tilt \\
\hline 13 & Surana Telecom \& Power Itd. & 5 & Crystalline Si & Surana & Central Inverter & AEG & Fixed Tilt \\
\hline 14 & GPCL & 5 & Crystalline Si & C-Sun & Central Inverter & Bonfiglioli & Seasonal Tilt \\
\hline 15 & ZF Steering Gear (India) pvt.Itd & 5 & Thin Film & Not Available & Central Inverter & Not Available & Seasonal Tilt \\
\hline 16 & Yantra eSolar India Pvt.Itd & 5 & Crystalline Si & Not Available & Central Inverter & Not Available & Fixed Tilt \\
\hline 17 & Avatar Solar Pvt. Ltd & 5 & Crystalline Si & Not Available & Central Inverter & Not Available & Fixed Tilt \\
\hline
\end{tabular}

Source: Primary Data (Visit to Charanka Solar Park)

V. Charanka Solar Park Generation for the year 2012:

\begin{tabular}{|c|l|c|c|c|c|c|c|c|c|c|c|c|c|c|}
\hline \multicolumn{10}{|c|}{ S.No } & \multicolumn{10}{|c|}{ Name of the Party } & $\begin{array}{c}\text { Capacity } \\
\text { (MW) }\end{array}$ & Mar-12 & Apr-12 & May-12 & Jun-12 & Jul-12 & Aug-12 & Sep-12 & Oct-12 & Nov-12 & Dec-12 & Total & $\begin{array}{c}\text { PLF } \\
\%\end{array}$ \\
\hline 1 & GMR Gujarat solar power pvt.Itd & 25 & 2318 & 3584 & 4066 & 3396 & 2557 & 2290 & 2901 & 3806 & 3415 & 3481 & 31813 & $17 \%$ \\
\hline 2 & Sun Clean Renewable pvt.Itd & 6 & 695 & 966 & 1029 & 856 & 638 & 605 & 777 & 970 & 840 & 852 & 8229 & $19 \%$ \\
\hline 3 & Emami Cement Itd & 10 & 1313 & 1437 & 1611 & 1397 & 1036 & 944 & 1189 & 1528 & 1344 & 1357 & 13157 & $18 \%$ \\
\hline 4 & Solarfield Energy Pvt. Ltd. & 20 & 2467 & 3281 & 3360 & 2891 & 2026 & 1833 & 2479 & 3224 & 2770 & 2833 & 27164 & $19 \%$ \\
\hline 5 & SEl Solar Power Gujarat pvt.Itd & 25 & 2342 & 3849 & 4001 & 3414 & 2548 & 2392 & 3070 & 4027 & 3603 & 3601 & 32847 & $18 \%$ \\
\hline 6 & GSPC Pipavav Power Company Itd. & 5 & 680 & 694 & 833 & 722 & 506 & 440 & 601 & 782 & 724 & 792 & 6774 & $19 \%$ \\
\hline 7 & AES Solar Energy Gujarat pvt. Ltd & 15 & 625 & 1267 & 2265 & 1925 & 939 & 694 & 955 & 2152 & 2067 & 2017 & 14907 & $14 \%$ \\
\hline 8 & Alex Astral Power pvt.Itd & 25 & 2745 & 3863 & 4434 & 3794 & 2654 & 2337 & 3147 & 4001 & 3363 & 3355 & 33693 & $18 \%$ \\
\hline 9 & NKG Infrastructure Itd & 10 & 1322 & 1577 & 1662 & 1418 & 1056 & 992 & 1245 & 1615 & 1450 & 1465 & 13803 & $19 \%$ \\
\hline 10 & Palace Solar Energy pvt.Itd & 15 & 1800 & 2467 & 2525 & 2210 & 1617 & 1380 & 1776 & 2300 & 2239 & 2334 & 20649 & $19 \%$ \\
\hline 11 & Roha Dyechem pvt.Itd & 25 & 3001 & 3900 & 4324 & 3672 & 2749 & 2512 & 3057 & 3895 & 3541 & 3634 & 34285 & $19 \%$ \\
\hline 12 & Lanco Infratech Itd. & 15 & 124 & 857 & 1265 & 1589 & 1020 & 1182 & 1608 & 2138 & 1974 & 2057 & 13814 & $13 \%$ \\
\hline 13 & Surana Telecom \& Power Itd. & 5 & 703 & 735 & 791 & 685 & 485 & 445 & 565 & 742 & 649 & 636 & 6437 & $18 \%$ \\
\hline 14 & GPCL & 5 & 264 & 668 & 761 & 642 & 430 & 434 & 568 & 756 & 677 & 708 & 5908 & $16 \%$ \\
\hline 15 & ZF Steering Gear (India) pvt.Itd & 5 & 582 & & 849 & 717 & 540 & 503 & 640 & 779 & 695 & 714 & 6018 & $16 \%$ \\
\hline 16 & Yantra eSolar India Pvt.Itd & 5 & & & & & & & & & 579 & 509 & 1088 & $15 \%$ \\
\hline 17 & Avatar Solar Pvt. Ltd & 5 & & & & & & & & & & & & \\
\hline & & 221 & & & & & & & & & & & & \\
\hline
\end{tabular}

Source: Gujarat State Load Dispatch Centre(SLDC) 
VI. Charanka Solar Park generation for the year 2013:

\begin{tabular}{|c|c|c|c|c|c|c|c|c|c|c|c|c|c|c|c|c|}
\hline \\
\hline S.No & Name of the Party & $\begin{array}{c}\text { Capacity } \\
\text { (MW) }\end{array}$ & Jan-13 & Feb-13 & Mar-13 & Apr-13 & May-13 & Jun-13 & Jul-13 & Aug-13 & Sep-1 & Oct-13 & Nov-13 & Dec-13 & $3 \mid$ Total & $\begin{array}{l}\text { PLF } \\
\%\end{array}$ \\
\hline 1 & GMR Gujarat solar power pvt.Itd & 25 & 3700 & 3559 & 4229 & 4075 & 4214 & 3168 & 2443 & 2798 & 3317 & 3838 & 3445 & 3640 & 42426 & $19 \%$ \\
\hline 2 & Sun Clean Renewable pvt.Itd & 6 & 885 & 868 & 1055 & 1023 & 1063 & 772 & 590 & 690 & 817 & 902 & 807 & 862 & 10332 & $20 \%$ \\
\hline 3 & Emami Cement Itd & 10 & 1455 & 1438 & 1574 & 1608 & 1707 & 1243 & 989 & 1117 & 1246 & 1466 & 1382 & 1420 & 16644 & $19 \%$ \\
\hline 4 & Solarfield Energy Pvt. Ltd. & 20 & 2897 & 2857 & 3498 & 3366 & 3491 & 2551 & 1934 & 2232 & 2660 & 2624 & 2719 & 2832 & 33661 & $19 \%$ \\
\hline 5 & SEI Solar Power Gujarat pvt.Itd & 25 & 3799 & 3715 & 4397 & 4090 & 4162 & 3079 & 2345 & 2764 & 3244 & 3812 & 3568 & 3793 & 42768 & $20 \%$ \\
\hline 6 & GSPC Pipavav Power Company Itd. & 5 & 826 & 764 & 886 & 806 & 872 & 649 & 453 & 569 & 662 & 775 & 741 & 828 & 8831 & $20 \%$ \\
\hline 7 & AES Solar Energy Gujarat pvt. Ltd & 15 & 2082 & 2067 & 2466 & 2360 & 2416 & 1845 & 1419 & 1594 & 1934 & 2225 & 1998 & 2092 & 24497 & $19 \%$ \\
\hline 8 & Alex Astral Power put.Itd & 25 & 3808 & 3491 & 4284 & 4330 & 4490 & 3324 & 2515 & 2895 & 3365 & 3839 & 3384 & 3599 & [43324] & $20 \%$ \\
\hline 9 & NKG Infrastructure Itd & 10 & 1556 & 1494 & 1780 & 1704 & 1748 & 1298 & 988 & 1150 & 1354 & 1530 & 1433 & 1525 & 17562 & $20 \%$ \\
\hline 10 & Palace Solar Energy pvt.ltd & 15 & 2463 & 2273 & 2589 & 2446 & 2657 & 1998 & 1537 & 1753 & 1891 & 2070 & 2230 & 2442 & 26350 & $20 \%$ \\
\hline 11 & Roha Dyechem pvt.Itd & 25 & 3764 & 3605 & 4246 & 4205 & 4555 & 3502 & 2627 & 2932 & 3067 & 3784 & 3500 & 3734 & 43521 & $20 \%$ \\
\hline 12 & Lanco Infratech Itd. & 15 & 2141 & 2077 & 2524 & 2331 & 2372 & 1746 & 1296 & 1441 & 1695 & 1902 & 1655 & 1741 & 22921 & $17 \%$ \\
\hline 13 & Surana Telecom \& Power Itd. & 5 & 690 & 683 & 808 & 779 & 804 & 578 & 422 & 501 & 587 & 651 & 640 & 652 & 7797 & $18 \%$ \\
\hline 14 & GPCL & 5 & 749 & 714 & 841 & 782 & 789 & 579 & 425 & 505 & 606 & 567 & 608 & 688 & 7853 & $18 \%$ \\
\hline 15 & ZF Steering Gear (India) pvt.Itd & 5 & 752 & 730 & 899 & 850 & 883 & 653 & 499 & 575 & 688 & 786 & 702 & 694 & 8711 & $20 \%$ \\
\hline 16 & Yantra eSolar India Pvt.Itd & 5 & 613 & 591 & 749 & 741 & 826 & 585 & 433 & 518 & 604 & 667 & 453 & 595 & 7374 & $17 \%$ \\
\hline 17 & Avatar Solar Pvt. Ltd & 5 & $\cdot$ & $\cdot$ & - & 541 & 695 & 565 & 449 & 511 & 619 & 699 & 632 & 634 & 5344 & $12 \%$ \\
\hline & & 221 & & & & & & & & & & & & & & \\
\hline
\end{tabular}

Source: Gujarat State Load Dispatch Centre (SLDC)

VII. Charanka Solar park generation for the year 2014:

\begin{tabular}{|c|l|c|c|c|c|c|c|c|}
\hline \multicolumn{9}{|c|}{ Charanka Solar Park Generation for the year 2014} \\
\hline S.No & \multicolumn{1}{|c|}{ Name of the Party } & $\begin{array}{c}\text { Capacity } \\
\text { (MW) }\end{array}$ & Jan-14 & Feb-14 & Mar-14 & Apr-14 & Total & $\begin{array}{c}\text { PLF } \\
\%\end{array}$ \\
\hline 1 & GMR Gujarat solar power pvt.Itd & 25 & 3746 & 3559 & 4318 & 4121 & 15744 & $22 \%$ \\
\hline 2 & Sun Clean Renewable pvt.Itd & 6 & 852 & 826 & 1045 & 1028 & 3751 & $21 \%$ \\
\hline 3 & Emami Cement Itd & 10 & 1452 & 1398 & 1674 & 1589 & 6113 & $21 \%$ \\
\hline 4 & Solarfield Energy Pvt. Ltd. & 20 & 2764 & 2678 & 3409 & 3296 & 12147 & $21 \%$ \\
\hline 5 & SEI Solar Power Gujarat pvt.Itd & 25 & 3808 & 3589 & 4264 & 4019 & 15679 & $21 \%$ \\
\hline 6 & GSPC Pipavav Power Company Itd. & 5 & 818 & 742 & 872 & 830 & 3263 & $22 \%$ \\
\hline 7 & AES Solar Energy Gujarat pvt. Ltd & 15 & 2059 & 1979 & 2428 & 2326 & 8793 & $20 \%$ \\
\hline 8 & Alex Astral Power pvt.Itd & 25 & 3607 & 3464 & 4322 & 4233 & 15625 & $21 \%$ \\
\hline 9 & NKG Infrastructure Itd & 10 & 1538 & 1459 & 1738 & 1712 & 6447 & $22 \%$ \\
\hline 10 & Palace Solar Energy pvt.Itd & 15 & 2390 & 2175 & 2545 & 2369 & 9480 & $22 \%$ \\
\hline 11 & Roha Dyechem pvt.Itd & 25 & 3604 & 3427 & 4171 & 4142 & 15345 & $21 \%$ \\
\hline 12 & Lanco Infratech Itd. & 15 & 1823 & 1725 & 1992 & 1888 & 7427 & $17 \%$ \\
\hline 13 & Surana Telecom \& Power Itd. & 5 & 667 & 650 & 803 & 770 & 2890 & $20 \%$ \\
\hline 14 & GPCL & 5 & 701 & 677 & 831 & 774 & 2984 & $20 \%$ \\
\hline 15 & ZF Steering Gear (India) pvt.Itd & 5 & 736 & 637 & 883 & 852 & 3109 & $21 \%$ \\
\hline 16 & Yantra eSolar India Pvt.Itd & 5 & 487 & 596 & 734 & 728 & 2545 & $17 \%$ \\
\hline 17 & Avatar Solar Pvt. Ltd & 5 & 649 & 667 & 822 & 765 & 2903 & $20 \%$ \\
\hline & & 221 & & & & & & \\
\hline
\end{tabular}

Source: Gujarat State Load Dispatch Centre (SLDC)

VIII. Ranking of various projects at Charanka Solar Park:

\begin{tabular}{|c|c|c|c|}
\hline S.No & Name of the Party & Average PLF (\%) & Ranking \\
\hline 1 & GMR Gujarat solar power pvt.Itd & $19.42 \%$ & 9 \\
\hline 2 & Sun Clean Renewable pvt.Itd & $19.92 \%$ & 4 \\
\hline 3 & Emami Cement Itd & $19.28 \%$ & 10 \\
\hline 4 & Solarfield Energy Pvt. Ltd. & $19.50 \%$ & 8 \\
\hline 5 & SEI Solar Power Gujarat pvt.Itd & $19.63 \%$ & 7 \\
\hline 6 & GSPC Pipavav Power Company ltd. & $20.32 \%$ & 1 \\
\hline 7 & AES Solar Energy Gujarat pvt. Ltd & $17.4 \%$ & 14 \\
\hline 8 & Alex Astral Power pvt.ltd & $19.85 \%$ & 6 \\
\hline 9 & NKG Infrastructure ltd & $20.31 \%$ & 2 \\
\hline 10 & Palace Solar Energy pvt.Itd & $20.1 \%$ & 3 \\
\hline 11 & Roha Dyechem pvt.Itd & $19.86 \%$ & 5 \\
\hline 12 & Lanco Infratech Itd. & $15.6 \%$ & 17 \\
\hline 13 & Surana Telecom \& Power ltd. & $18.38 \%$ & 12 \\
\hline 14 & GPCL & $18.15 \%$ & 13 \\
\hline 15 & ZF Steering Gear (India) pvt.Itd & $19.19 \%$ & 11 \\
\hline 16 & Yantra eSolar India Pvt.Itd & $16.4 \%$ & 15 \\
\hline 17 & Avatar Solar Pvt. Ltd & $16.0 \%$ & 16 \\
\hline
\end{tabular}


Inference:

> The ranking of the plants considered with the generation data available from March-2012 to April2014.

> Plant load factor(PLF $)=($ Actual Generation $) /($ Capacity of the Project X 365 days X $24 \mathrm{Hrs})$

$>$ The energy yield of the plant will depend on the several factors like type of modules, inverters, usage of tracking system, design optimization and build quality.

$>$ The ranking of the plants is based on only the energy yield but did not considered any factors above.

$>$ The first ranking goes to GSPC Pipavav Power Company ltd with a PLF of 20.32\%.Lanco Infra was the EPC contractor. Crystalline modules (Make- Suntech), Central inverter(Make- Bonfiglioli) and fixed tilt were used.

$>$ The second ranking goes to NKG Infrastructure Ltd with a PLF of 20.31\%. PPS Enviro Power was the EPC contractor. Crystalline modules (Make- Sun World), String Inverter (Make - Delta) and fixed tilt were used.

$>$ The third ranking goes to Palace Solar Energy Pvt Ltd with a PLF of 20.1\%. EttainImmodo was the EPC contractor. Crystalline modules (Make - Canadian Solar), Central Inverter (Make- Power one) and Seasonal tilt were used.

\section{Crystalline V/S Thinfilm Technology}

\begin{tabular}{|l|c|c|c|c|c|c|c|c|c|c|c|c|}
\hline Technology & January & February & March & April & May & June & July & August & September & October & November & December \\
\hline Crystalline & 144.5 & 139.3 & 144.1 & 149.5 & 159.1 & 128.7 & 94.6 & 99.1 & 121.2 & 146.7 & 133.6 & 139.8 \\
\hline Thinfilm & 144.8 & 138.5 & 149.2 & 158.0 & 171.8 & 136.7 & 99.1 & 101.2 & 123.9 & 152.5 & 137.6 & 141.4 \\
\hline
\end{tabular}

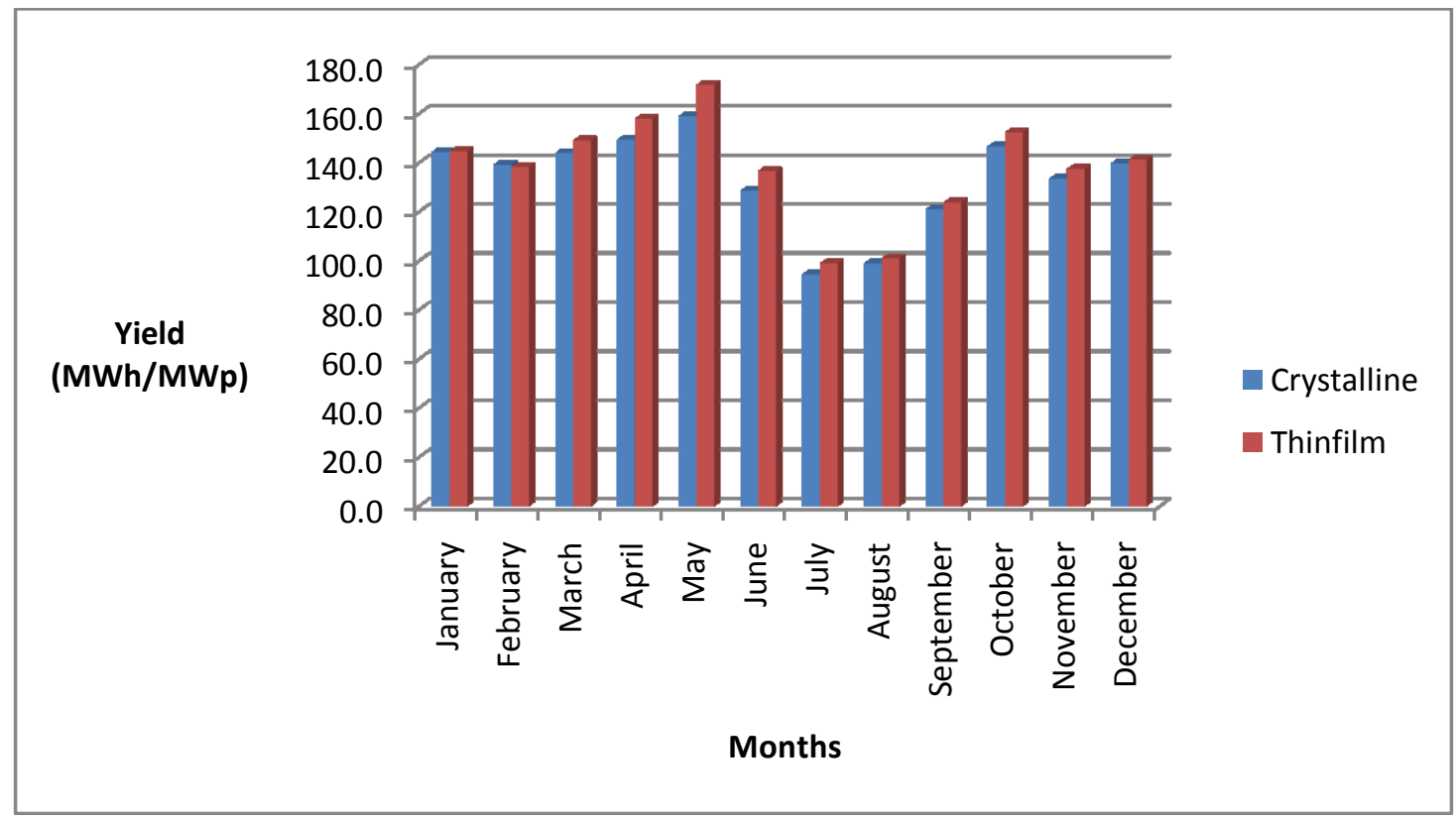

\section{Inferences:}

$>$ Out of 17 projects in the solar park 11 projects have used Crystalline technology and 6 project have used thin film technology.

$>$ While analysing the results, it can be seen that the Thin film modules perform better than the Crystalline modules with an average performance advantage of about $0.77 \%$

$>$ Thin film modules have higher generation than plants using crystalline modules in hotter months while crystalline modules are with par with thin film in colder months which can be attributed to the lower temperature de-rating coefficient of thin film modules compared to crystalline modules.

$>$ Thin film usually generates more during the initial years and they degrade more within 5-7 years.

$>$ Thin film performs better with diffused radiation. 
X. Module Mounting Structure: Fixed V/S Seasonal Tilt

\begin{tabular}{|l|c|c|c|c|c|c|c|c|c|c|c|c|}
\hline Module Mounting Structure January & February & March & April & May & June & July & August & September & October & November & December \\
\hline Fixed Tilt & 142.4 & 138.0 & 144.6 & 150.9 & 161.6 & 130.3 & 94.2 & 98.0 & 121.4 & 149.4 & 133.4 & 138.3 \\
\hline Seasonal Tilt & 149.6 & 141.3 & 149.0 & 156.3 & 168.9 & 135.0 & 100.7 & 103.6 & 123.3 & 147.5 & 138.9 & 145.2 \\
\hline
\end{tabular}

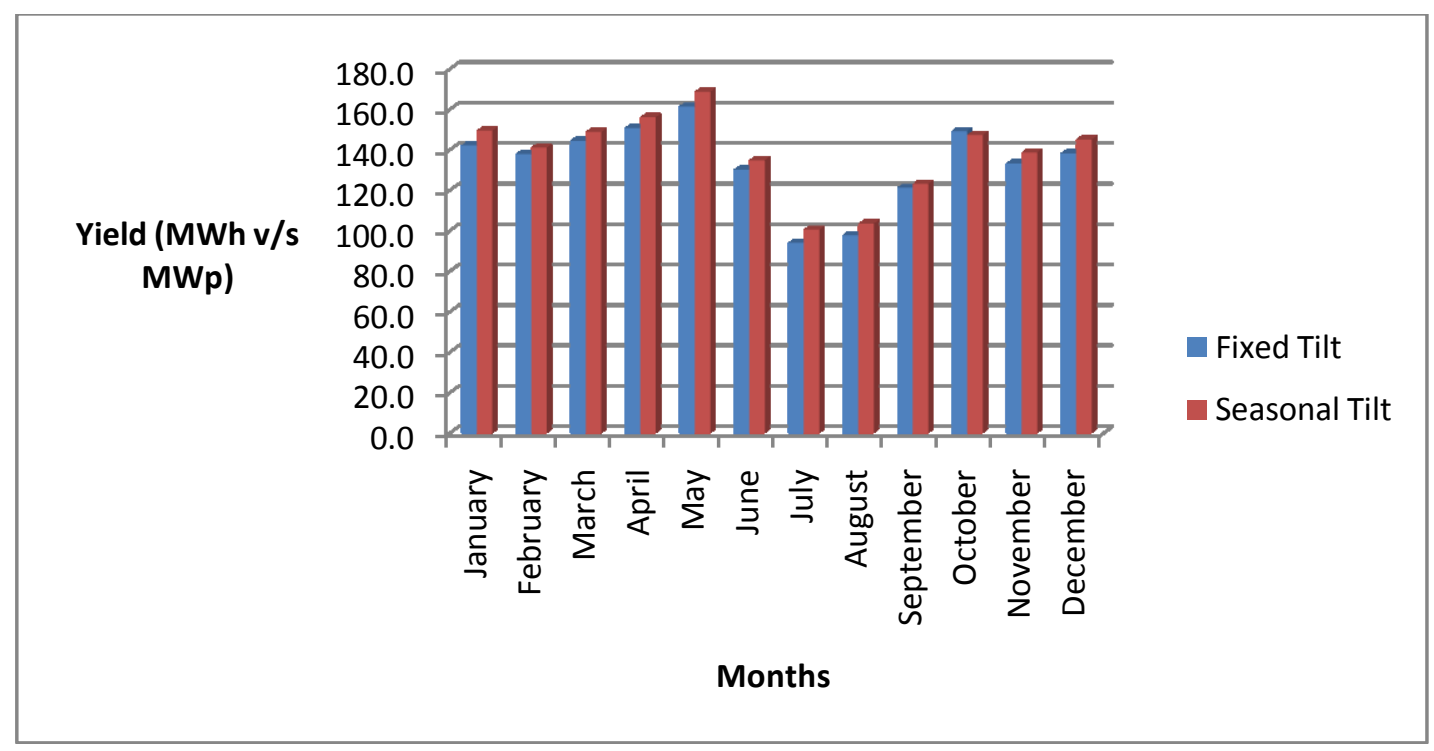

Inferences:

$>$ Except in the month of October, Seasonal tilt module mounting structure generates more than the fixed tilt.

$>$ By using seasonal tilt, the overall generation goes up to $5 \%$ with the minimal cost increase as of fixed axis.

XI. Inverters: Central V/S String Inverter

\begin{tabular}{|l|c|c|c|c|c|c|c|c|c|c|c|c|}
\hline Inverters & January & February & March & April & May & June & July & August & September & October & November & December \\
\hline Central Inverter & 139.3 & 134.0 & 137.2 & 145.9 & 153.5 & 122.8 & 89.8 & 93.7 & 114.3 & 138.6 & 130.2 & 135.5 \\
\hline String Inverter & 154.7 & 147.6 & 161.3 & 166.4 & 170.5 & 120.3 & 102.2 & 107.1 & 129.9 & 157.2 & 144.2 & 149.5 \\
\hline
\end{tabular}

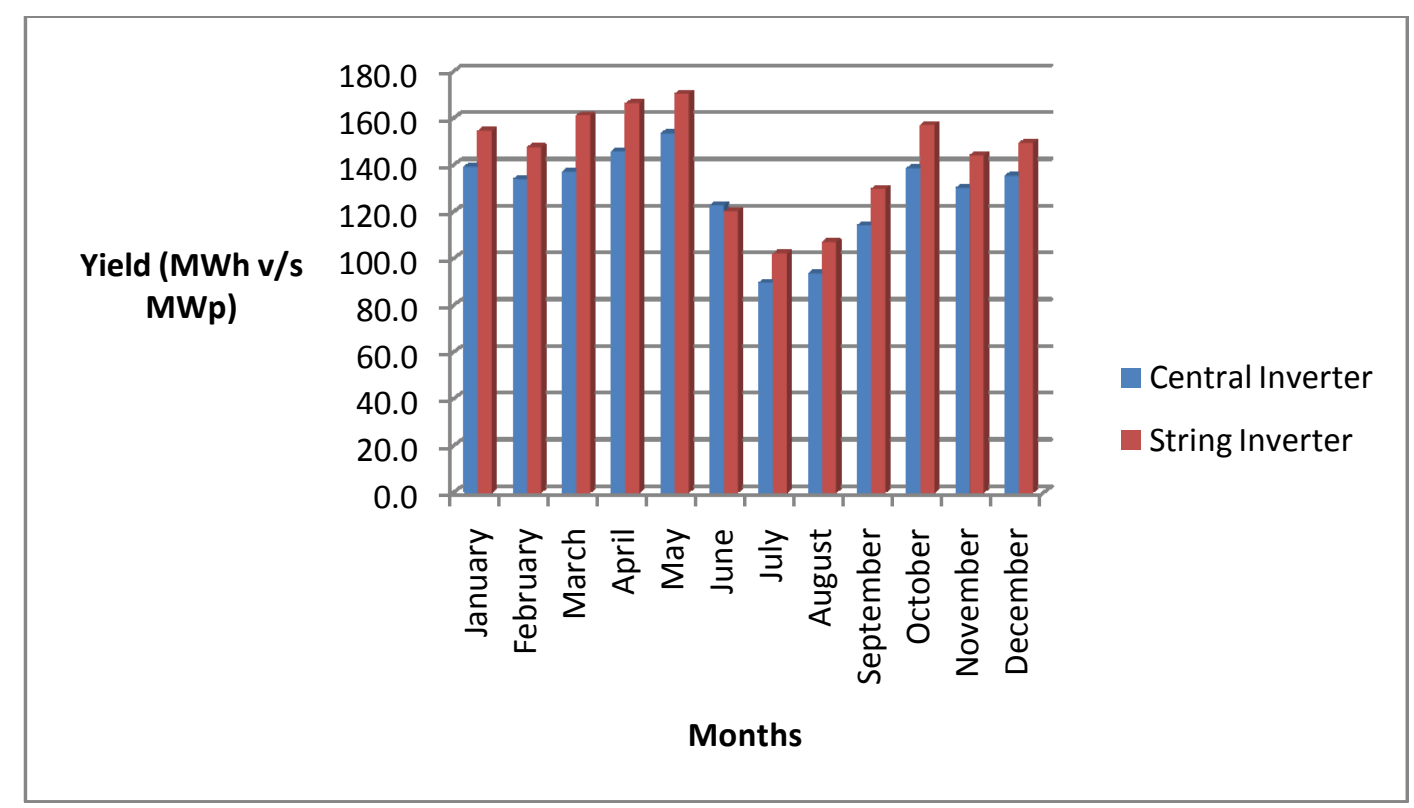




\section{Inferences:}

$>$ String inverters offer better performance as opposed to central inverter.

$>$ String inverter has more Maximum Power Point Tracking (MPPT's) and hence a better MPPT window when compared to plants using central inverter.

$>$ By using string inverters optimum utilization of ground area is possible.

$>$ By using string inverters reduced effect of shading is possible.

$>$ Due to high number of independently working inverters the total system output will only be limited affected even if there is a high degree of output variation of modules in your plant.

> By using a string inverter solution you get the flexibility, yield and efficiency expected from a modern day PV system as well as fast and reliable installation and commissioning and a full monitoring solution.

XII. Average Generation Month Wise:

\begin{tabular}{|c|c|c|c|c|c|c|c|c|c|c|c|c|}
\hline Months & January & February & March & April & May & June & July & August & September & October & November & December \\
\hline Generation & 144.6 & 139.0 & 146.0 & 152.6 & 163.9 & 131.7 & 96.3 & 99.8 & 122.1 & 148.8 & 135.0 & 140.4 \\
\hline
\end{tabular}

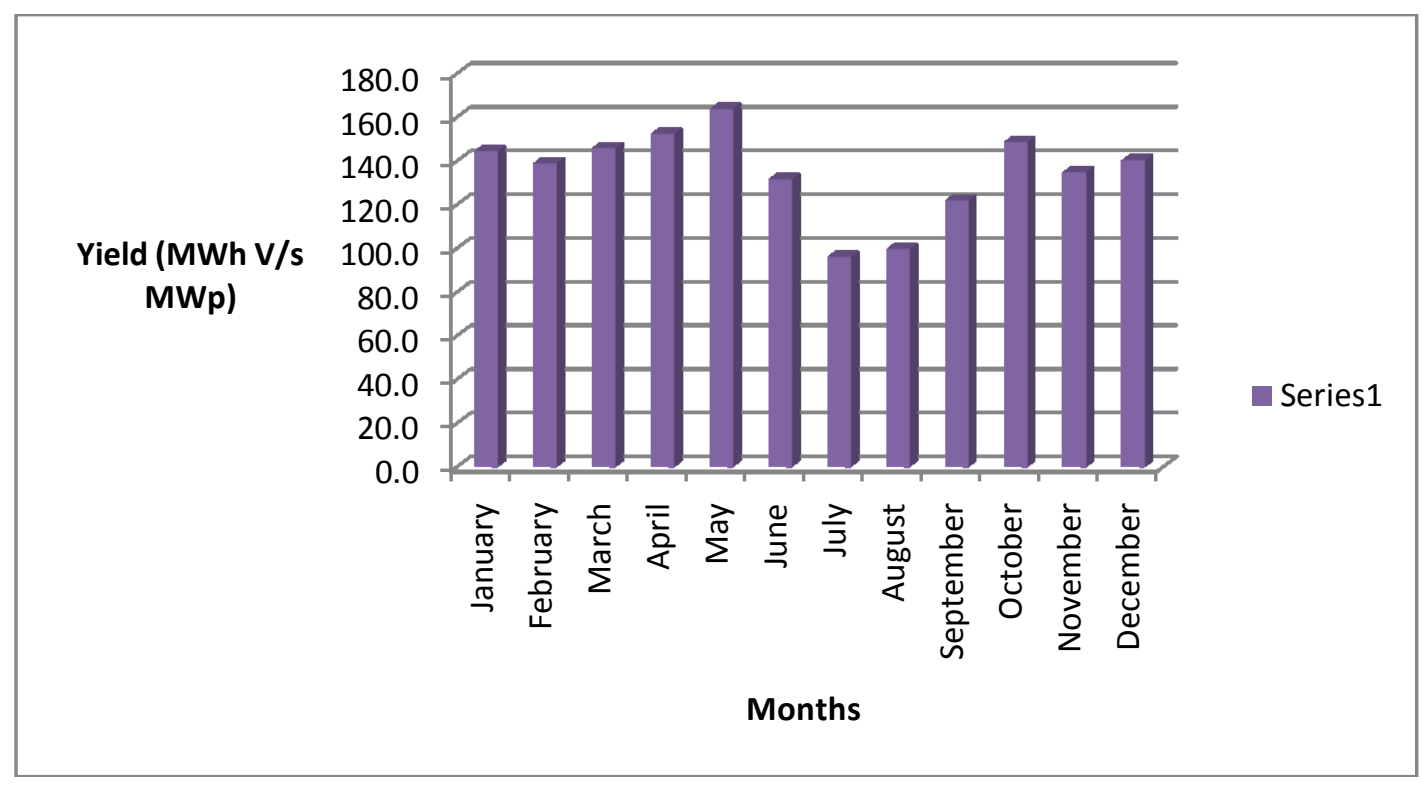

\section{Inferences:}

$>$ From the table above we can see the maximum generation happens in the month of May

$>$ The secondary peak is seen in the month of April followed by October.

$>$ The lowest generation happens in the month of July followed by August. This is may be due to rainy season.

$>$ Out of all the seasons in summer the generation is very high because of good solar insolation.

$>$ The overall average generation comes to around $16,20,000$ units which is around $18.5 \%$ plant load factor.

\section{Conclusion:}

Of the 17 plants for which performance data is available for last 26 months, the annual plant load factor for $76 \%$ of the plants is above $18 \%$. The top three plants had plant load factor of more than $20 \%$. One very interesting insight that can be drawn from the performance ranking is that the right components selection is necessary, but not sufficient condition for the optimal performance of the plant. Fox example one of the plant using C-Sun modules and Bonfiglioli inverter has a plant load factor of $18.15 \%(\mathrm{GPCL})$ but another plant using the same configuration of C-Sun modules and Bonfiglioli inverter has a plant load factor of $15.6 \%$ (lanco Infra). One inference that could be drawn is that a developer should pay equal attention to the selection of the balance of system components, ensure design optimization and select the right Engineering Procurement and Construction(EPC) contractor who can ensure build quality and high plant uptimes. Another aspect that could have an impact on the plan's PLF is operation and maintenance of the plant. A plant that has a very good performance monitoring system (remote monitoring or local SCADA) and is well maintained will obviously lead to higher generation. 
In terms of PV module technology selection thin film technology plants are generating more than Crystalline technology plants. In order to draw any conclusion we have to wait for longer term performance of the plants as thin film has tendency to degrade at a faster rate.Comparison between Central and String inverter is difficult to conclude as there is only one plant which is working on string technology. Although we can infer that string technology plant performance is more than the average of central inverter technology plants.In terms of module mounting structure between fixed tilt and seasonal tilt, seasonal tilt plants performance is good but one has to work on the cost economics before taking a decision. To conclude the plant performance data made available by the State of Gujarat has been providing some very valuable insights into the PV plant performance.

\section{References}

[1]. Gujarat State Load Dispatch Centre

[2]. Gujarat Solar Park Plant Performance by Resolve Energy

[3]. Gujarat State Electricity Regulatory Commission

[4]. Gujarat State Electricity Generation Commission

[5]. Gujarat Power Corporation Ltd. 